CATALLAXY

Volume 3 Issue 1 June 2018

e-ISSN 2544-090X

¿ www.catallaxy.pl

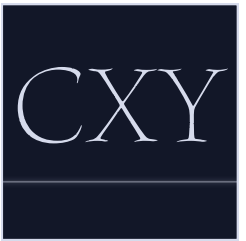

Oryginalny artykut naukowy

otrzymano: 09.05.2018 / zaakceptowano: 25.06.2018 / opublikowano online: 30.06 .2018

Pudło, D. (2018). Czynniki determinujące zmiany na rynku kryptowalut. Catallaxy, 3(1): 55-64.

doi:10.24136/cxy.2018.001.

\title{
Czynniki determinujące zmiany na rynku kryptowalut
}

\author{
DAMIAN PUDEO \\ Uniwersytet Mikołaja Kopernika w Toruniu, Wydział Nauk Ekonomicznych i Zarządzania, ul. Gagarina 13a, \\ 87-100 Toruń, Polska \\ ๑waz55555@gmail.com \\ (D) orcid.org/0000-0002-1711-5758
}

\begin{abstract}
Abstrakt
Motywacja: Obecnie na rynku kryptowalut zachodzą istotne zmiany, których odzwierciedleniem są wahania kapitalizacji całego rynku, jak również poszczególnych kryptowalut. W literaturze przedmiotu brakuje opisu tych przemian z wyodrębnieniem czynników, które je wywołują. Korzyści z likwidacji istniejącej luki poznawczej były głównym motywem wyboru tematyki niniejszego artykułu.

Cel: Celem artykułu jest wyszczególnienie czynników, które wpływały zarówno pozytywne, jak i negatywne na wartość kapitalizacji rynku kryptowalut, tj. korektę rynku, która miała miejsce pod koniec maja 2017 roku, hossę, którą odnotowano w drugiej połowie listopada 2017 roku oraz kryzys z połowy stycznia 2018 roku.

Materiały i metody: W celu określenia dynamiki zmian, porównywano kapitalizację, zarówno poszczególnych kryptowalut, jak i calego rynku. Dane odnośnie kapitalizacji rynku oraz cen poszczególnych walut cyfrowych pochodzą z portalu CoinMarketCap. Analizie poddano następujące kryptowaluty: Bitcoin, Ethereum oraz Ripple. Ich wybór wynika z faktu, że zmiany ich ceny mają największe znaczenie dla kapitalizacji całego rynku. Zakres czasowy artykułu obejmuje okres od 20.04.2017 roku do 20.04.2018 roku. Wybór ten podyktowany był wzrostem popularności kryptowalut, ich pojawieniem się w świadomości wielu nowych odbiorców za pośrednictwem mass mediów oraz zwiększeniem intensywności działań rządów mających na celu wprowadzenie kolejnych regulacji rynku.

Wyniki: Rynek kryptowalut, z uwagi na swoją niezależność od jakiejkolwiek gospodarki narodowej, nie jest uzależniony od nastrojów inwestycyjnych na giełdach poszczególnych państw. Jako główne przyczyny zmian cen wyodrębniono natomiast takie czynniki, jak: regulacje, obostrzenia podatkowe, akceptacja płatności kryptowalutami, opinie ekspertów, intensywność przekazu medialnego oraz indywidualne decyzje większych inwestorów.
\end{abstract}

Stowa kluczowe: kryptowaluty; nastroje rynkowe; Bitcoin; Ethereum; Ripple

JEL: F32; G12; 031

\section{Wprowadzenie}

W 2017 roku temat kryptowalut dotarł do wielu ludzi, którzy niekoniecznie posiadają wiedzę o inwestowaniu. Znaczna część początkujących inwestorów, na fali optymizmu, postanowiła ulokować część środków właśnie na rynku walut cyfrowych. Możliwość szybkiego zysku sprawiła, że podstawowa idea powstania walut kryptograficznych, jaką było dokonywanie szybkich i tanich transakcji z pominięciem sektora bankowego, odeszła na drugi plan. Nie spełniają one obecnie podstawowych funkcji, które posiada pieniądz klasyczny (nie są środkiem tezauryzacji, ponieważ nie mają stabilnego kursu). Pojawia 
się również coraz więcej propozycji kolejnych regulacji tego rynku czy różnych form jego opodatkowania. Skutkiem tego, kursy kryptowalut podlegają ciągłym perturbacjom i niemożliwe jest prognozowanie ich przyszłej wartości. Mimo wielu sceptycznych opinii znaczących inwestorów giełdowych na temat kryptowalut, duże grono osób pomnożyło swoje środki dzięki inwestycjom w te aktywa finansowe. Kryptowaluty przyczyniły się również do wielu bankructw.

Celem artykułu jest wyszczególnienie czynników, które wpływały zarówno pozytywne, jak i negatywne na wartość kapitalizacji rynku kryptowalut, tj. korektę rynku, która miała miejsce pod koniec maja 2017 roku, hossę, którą odnotowano w drugiej połowie listopada 2017 roku oraz kryzys z połowy stycznia 2018 roku.

W sekcji 2. dokonano przeglądu literatury przedmiotu. W sekcji 3. przedstawiono opis wykorzystanych materiałów i metod. W sekcji 4. omówiono strukturę rynku ze szczególnym uwzględnieniem kryptowalut o największej kapitalizacji: Bitcoina, Ethereum i Ripple. W kolejnych sekcjach scharakteryzowano najważniejsze wydarzenia mające miejsce na rynku kryptowalut $w$ analizowanym okresie, tj. korektę (sekcja 5.), hossę (sekcja 6.) oraz kryzys (sekcja 7.). W sekcji 8. zawarto główne wnioski płynące $z$ przeprowadzonej analizy. Sekcja 9. stanowi podsumowanie rozważań.

\section{Przegląd literatury}

Omówieniem tematu walut cyfrowych, w szczególności Bitcoina, i jego zastosowaniem w polskich realiach zajęła się A.I. Piotrowska (2018, ss. 154-170). Przeprowadziła ona badanie ankietowe pośród użytkowników kryptowalut w Polsce. Zgodnie $z$ jego wynikami, Polacy używali kryptowalut głównie do celów inwestycyjnych, a nie transakcyjnych. Dużą grupę inwestorów stanowili spekulanci, którzy inwestowali krótkoterminowo, a mniejszą inwestorzy długoterminowi. Interesujący jest także fakt, że inwestorzy długoterminowi deklarowali większą wiedzę na temat poszcze- gólnych kryptowalut niż spekulanci. Miało to związek $z$ dużym zaufaniem do poszczególnych walut cyfrowych oraz pozytywnymi prognozami rozwoju całego rynku.

Inwestowanie w kryptowaluty wiąże się $z$ różnego rodzaju ryzykiem, które wynika m.in. z (Piech, 2017, s. 50):

- wysokiej zmienności kursów,

- ciągłości notowań,

- podatności na wydarzenia dotyczące kryptowalut,

- baniek spekulacyjnych.

Wszystkie te czynniki miały bezpośredni związek $z$ perturbacjami na rynku kryptowalut.

Natomiast P. Kwiecień (2017, s. 23), uważa, że główną determinantą ceny kryptowalut jest koszt wydobycia jednej jednostki kryptowaluty. W takim przypadku kluczową rolę, przy kreowaniu ceny danej waluty cyfrowej, odgrywałyby: cena prądu, cena komputerów z odpowiednią mocą przerobową oraz liczba tzw. kopaczy.

$Z$ uwagi na stosunkową stabilność wymienionych czynników względem cen kryptowalut, nie stanowi to wiarygodnego wytłumaczenia gwaltownych zmian cen kryptowalut.

Powodem niestabilności cen kryptowalut może być wskazana przez K. Kądziołkę (2016, ss. 61-64), niezależność walut cyfrowych od emitentów instytucjonalnych oraz ich globalny charakter, przez który ich kursy nie są powiązane $z$ koniunkturą żadnej gospodarki.

\section{Materiały i metody}

Materiał empiryczny niniejszego artykułu stanowią dane dotyczące wartości kapitalizacji oraz ceny jednostkowej poszczególnych kryptowalut, publikowane przez serwis CoinMarketCap (2018). Przeanalizowano publikacje dotyczące tematyki kryptowalut oraz doniesienia medialne odnoszące się bezpośrednio lub pośrednio do rynku kryptowalut. W artykule zastosowano analizę opisową i porównawczą. 


\section{Struktura rynku}

20.04.2018 roku o godzinie 00:00 kapitalizacja rynku kryptowalut wyniosła $357602 \mathrm{mln}$ USD. Największą kapitalizacją, wynoszącą 140777 mln USD (39,0\% kapitalizacji rynku) charakteryzował się Bitcoin. Udział Ethereum w ogólnej kapitalizacji rynku wynosił około 15,5\% (56 189 mln USD). Kapitalizacja Ripple wynosiła $30953 \mathrm{mln}$ USD, a więc około 8,5\% kapitalizacji rynku (CoinMarketCap, 2018). W sekcjach 4.1., 4.2. i 4.3. niniejszego artykułu przedstawiono charakterystykę tych kryptowalut.

\subsection{Bitcoin}

Bitcoin jest pierwszą, a zarazem najbardziej popularną kryptowalutą, która powstała w 2009 roku. Jego twórcą prawdopodobnie jest S. Nakamoto. Jednostki kryptowaluty mogą być przechowywane bezpośrednio w portfelu indywidualnym na komputerze posiadacza lub w zewnętrznym serwisie zajmującym się magazynowaniem portfeli $z$ kryptowalutą. Niezależnie od tego, czy właściciel posiada folder swojego portfela na własnym komputerze, czy też zarządza nim poprzez serwis przechowujący portfele, może on w każdej chwili, przy pomocy Internetu, zrealizować przesył waluty do innego posiadacza adresu bitcoin. Przesyłać można nawet 0,00000001 części Bitcoina. Jest on zdecentralizowany i nie podlega on żadnemu emitentowi instytucjonalnemu. Funkcjonuje on za sprawą sieci korzystających z niego użytkowników, którzy wzajemnie autoryzują wykonywane w sieci transakcje. Obecnie, co 10 minut pojawia się nowe 12,5 jednostki Bitcoina. Docelowa podaż tej kryptowaluty jest ściśle określona i będzie ona stopniowo zwiększana, aż do osiągnięcia ilości 21 mln jednostek. Każdy użytkownik jest jawny, a cała historia przepływu danej jednostki jest zapisywana na blockchain, czyli magazynie danych. Daje to możliwość sprawdzenia czy druga osoba jest w posiadaniu określonej ilości kryptowaluty (Nakamoto, 2008).

\subsection{Ethereum}

Ethereum to kryptowaluta powstała w 2013 roku, której twórcą jest Rosjanin V. Buterin. Sieć została zaprojektowana przez przedsiębiorstwo Ethereum Switzerland $\mathrm{GmBH}$, a pierwsze jednostki zostały rozdzielone osobom, które, wykorzystując crowdfunding, przyczynity się do powstania Ethereum. Ethereum, tak jak Bitcoin, bazuje na technologii blockchain, przy czym w tym przypadku bloki są mniejsze, a czas weryfikacji transakcji znacznie szybszy z uwagi na mniej przeciążoną sieć. Kryptowaluta ta, podobnie jak Bitcoin, jest niezależna od żadnego państwa czy emitenta. Jej podaż jest nieograniczona i zwiększa się o 5 jednostek w regularnych odstępach czasu wynoszących 15s. Konsekwencją nieograniczonej podaży, która rośnie w szybkim tempie, bez wątpienia będzie spadek wartości. Popyt $\mathrm{w}$ pewnym momencie przestanie się zwiększać, a podaż będzie stale rosła, co spowoduje deprecjację kryptowaluty. Dodatkowo, Ethereum różni się od pozostałych kryptowalut tym, że oprócz powszechnie stosowanej metody wydobywania waluty za pomocą udostępniania mocy przerobowej komputera (proof-of-work), ma zostać wprowadzona także możliwość uzyskania dodatkowych jednostek, $z$ racji posiadania już obecnych $w$ swoim portfelu (proof-of-stake) (Ethtrade, 2016).

\subsection{Ripple}

Ripple powstał w 2012 roku, a jego twórcą jest C. Larsen. Ripple miał służyć do celów transakcyjnych, a nie spekulacyjnych. Kryptowaluta ta funkcjonuje $w$ obrocie międzybankowym i ma za zadanie usprawnić przesył środków przy poniesieniu stosunkowo małych kosztów. Weryfikacja przeciętnej transakcji trwa około $4 \mathrm{~s}$ i jest kompatybilna z systemami bankowymi, więc spełnia ona swoją podstawową funkcję. Transakcje mogą być realizowane dzięki modułowi xCurrent, który jest częścią zintegrowanego systemu o nazwie Ripplenet. Umożliwia on księgowanie płatności praktycznie $\mathrm{w}$ czasie rzeczywistym oraz przewalutowanie przelanych środków po ak- 
tualnym kursie, bez ponoszenia dodatkowych opłat manipulacyjnych. Podstawowym aspektem, który różni Ripple od pozostałych kryptowalut jest to, że tylko część jednostek (około $40 \mathrm{mld}$ ) jest rozproszona i bierze udział w obiegu rynkowym, a około $60 \%$ podaży jest w posiadaniu spółki Ripple Llabs. Dla wielu inwestorów może to stanowić duży problem, ponieważ twórca kryptowaluty może w każdej chwili wprowadzić jej znaczną ilość rynek i spowodować znaczne perturbacje, które mogą skutkować czasową zwyżką kursu (Buterin, 2013).

\section{Korekta rynku kryptowalut od 26.05.2017 roku do 27.05.2017 roku}

W tabeli 1. przedstawiono wartość kapitalizacji na rynku kryptowalut w wybranych dniach oraz jej zmianę procentową.

Kluczowym momentem był 26.05.2017 roku, gdy po osiągnięciu kapitalizacji na poziomie 86,79 mld USD o godz. 11:00, nastąpił jej spadek. Wywołało to niepokój na rynku połączony $z$ wyprzedażą aktywów przez inwestorów. Wartość kapitalizacji rynku spadała, aż do godziny 12:30 dnia następnego (27.05.2017 roku). W 25,5h kapitalizacja rynku spadła do wartości 58,00 mld USD (o 34,25\%) (CoinMarketCap, 2018).

W tym samym czasie, kapitalizacja Bitcoina zmniejszyła się z 41,78 mld USD do 30,35 mld USD (o 27,36\%). Zanotowany, procentowy spadek był mniejszy niż procentowy spadek wartości całego rynku kryptowalut. Cena jednostki uległa znacznemu spadkowi z 2554,76 USD do 1 855,83 USD (CoinMarketCap, 2018).

Kapitalizacja Ethereum uległa większej perturbacji ( $z$ 17,78 mld USD do 11,33 mld USD). W tym przypadku procentowy spadek kapitalizacji był większy niż całego rynku i wyniósł $36,28 \%$. Cena jednostki uległa znacznemu spadkowi z 193,32 USD do 123,18 USD (CoinMarketCap, 2018).

W przypadku kapitalizacji Ripple zanotowano największy spadek ze wszystkich, analizowanych kryptowalut ( $z$ 11,71 mld USD do
6,34 mld USD, o 45,86\%). Cena jednostki uległa znacznemu spadkowi z 0,31 USD do 0,17 USD (CoinMarketCap, 2018).

W omawianych dniach $w$ gospodarce światowej nie nastąpiły żadne wydarzenia, które mogłyby mieć wpływ na rynek kryptowalut. Spadek wartości rynku walut cyfrowych był spowodowany paniką na rynku. Po serii wzrostów, część inwestorów postanowiła sprzedać z zyskiem swoje aktywa finansowe, co spowodowało nadwyżkę podaży nad popytem. Sprzedawcy zaczęli zmniejszać cenę, aby jak najszybciej przekonwertować kryptowalutę na walutę klasyczną. Spowodowało to reakcję pozostałych inwestorów, którzy widząc zmniejszające się ceny, postanowili pozbyć się części zawartości portfela inwestycyjnego. Takie zjawisko nazywane jest korektą rynku i zazwyczaj przejawia się w cyklicznych, tymczasowych przecenach jednostek. Po tym tąpnięciu, rynek bardzo szybko odzyskał kapitalizację sprzed kryzysu. W przypadku ogółu rynku oraz Ripple, miało to miejsce 1.06.2017 roku, w przypadku Bitcoina 3.06.2017 roku, natomiast Ethereum już 30.05.2017 roku (CoinMarketCap, 2018).

\section{Hossa na rynku kryptowalut od 15.11.2017 roku do 21.12.2017 roku}

W okresie od 15.11.2017 roku do 21.12.2017 roku na rynku kryptowalut panowało znaczne ożywienie, chwilowe spadki kapitalizacji rynku nie przekraczały $20 \%$.

15.11.2017 roku całkowita kapitalizacja rynku wynosiła 212,08 mld USD, a 21.12.2017 roku już 646,75 mld USD, co stanowiło $204,96 \%$ wzrost kapitalizacji całego rynku (tabela 1.) (CoinMarketCap, 2018).

W tym samym czasie, kapitalizacja Bitcoina zwiększyła się z 110,12 mld USD do 291,78 mld USD (o 164,96\%). Procentowy wzrost wartości Bitcoina był mniejszy niż procentowy wzrost wartości całego rynku kryptowalut. Cena za jednostkę Bitcoina uległa znacznemu wzrostowi z 6 602,15 USD do 17 414,90 USD (CoinMarketCap, 2018). 
Wartość kapitalizacji Ethereum wzrosła z 32,09 mld USD do 84,16 mld USD. Procentowy wzrost kapitalizacji był mniejszy w porównaniu do całego rynku oraz Bitcoina i wyniósł 162,26\%. Cena za jednostkę Ethereum uległa znacznemu wzrostowi z 335,19 USD do 872,35 USD (CoinMarketCap, 2018).

Wartość kapitalizacji Ripple wzrosła najbardziej ze wszystkich, analizowanych kryptowalut (z 8,06 mld USD do 52,42 mld USD, o 550,37\%). Cena jednostki uległa znacznemu wzrostowi z 0,21 USD do 1,35 USD (CoinMarketCap, 2018).

W tym czasie miało miejsce wiele wydarzeń, które najprawdopodobniej przyczynity się do poprawy koniunktury rynku kryptowalut.

21.11.2017 roku N. Nikiforow, który pełnił rolę ministra komunikacji i mass mediów w rosyjskim rządzie oznajmil, że Rosja, jako państwo, nie będzie w żaden sposób ingerować w rynek kryptowalut, ponieważ nie można osiągnąć rozwoju gospodarczego nakładając ograniczenia na innowacje technologiczne (Sundararajan, 2017).

21.11.2017 roku M. Draghi, który pełnił funkcję szefa Europejskiego Banku Centralnego (EBC) uznał, że nie warto regulować tego rynku, ponieważ jego udział jest znikomy i nie ma żadnych powodów, aby Bitcoin, czy też inne kryptowaluty, miałby zagrozić realizacji celów banków centralnych, czy też innych instytucji finansowych (De, 2017b).

25.11.2017 roku A. Firouzabadi, sekretarz organu ds. cyberprzestrzeni przy rządzie Iranu uznał, że zarówno Bitcoin, jak i reszta walut cyfrowych, może być uznana za środek płatniczy, ale istnieje konieczność ustalenia konkretnych zasad, które umożliwią rozstrzyganie potencjalnych sporów (Financial Tribune, 2017).

05.12.2017 roku ogłoszono, że kryptowalutą Monero można zapłacić za albumy muzyczne ponad czterdziestu artystów. Miało to związek z projektem Coral Reef realizowanym przez twórcę tej kryptowaluty R. Spagni (Higgins, 2017).
Od 05.12.2017 roku Bitcoinem oraz Ethereum można płacić za podróże liniami lotniczymi All-You-Can-Fly. Linie latają z lotnisk w Kalifornii, Teksasu oraz niektórych miast w Europie. Prezes przedsiębiorstwa S. Shahani stwierdził, że od dawna monitorował rynek kryptowalut, i dzięki jego prężnemu rozwojowi, może skierować swoją ofertę do szerszego grona odbiorców (De, 2017a).

11.12.2017 roku C. Noltinga, zajmujący stanowisko globalnego szefa Deutsche Bank stwierdził, że kryptowaluty oraz technologia blockchain staną się filarem światowej gospodarki i dzięki nim będzie możliwe przyśpieszenie tempa wzrostu gospodarczego. Stanie się tak na skutek usprawnienia przesyłania środków pieniężnych oraz informacji bez instytucji pośredniczących (De, 2017c).

18.12.2017 roku B. Miller, właściciel funduszu inwestycyjnego Pro Miller oświadczył, że aż 50\% funduszu MVP1 (Miller Value Partners), stanowi Bitcoin i $w$ dużej mierze dzięki temu, wartość funduszu w przeciągu 2,5 miesiąca wzrosła o $154 \mathrm{mln}$ USD. Uznał także, że osoby i instytucje, które miały niepochlebne zdanie na temat walut cyfrowych, nie posiadały na ich temat wystarczającej wiedzy (Zhao, 2017).

$\mathrm{W}$ analizowanym okresie, na rynku panowały pozytywne nastroje, a dzięki zwiększonej intensywności informacji podawanych w mediach na temat Bitcoina i jego wartości, powiększyło się grono zainteresowanych inwestowaniem. Duży wpływ na dobrą koniunkturę miały także pochlebne wypowiedzi wielu znanych ludzi z branży inwestycyjnej i bankowej. Wzrost liczby instytucji tolerujących płatności za pomocą kryptowalut miał również wpływ na zwiększenie zaufania do rynku. Dodatkowo, w tym czasie nie zostały wprowadzone żadne obostrzenia dotyczące handlu czy też wydobycia kryptowalut w państwach, w których obroty były największe. Wszystkie te czynniki sprawiły, że zaistniały warunki do zwiększania wartości kapitalizacji i wzrostu ceny poszczególnych walut cyfrowych. 
7. Kryzys na rynku kryptowalut od 16.01.2018 roku do 17.01.2018 roku

16.-17.01.2018 roku panował największy krach na rynku kryptowalut, który miał miejsce po opisanej w sekcji 6. hossie. W ciągu dwóch dni, kapitalizacja rynku uległa drastycznemu spadkowi $z$ wartości 703,38 mld USD, którą można było obserwować 16.01.2018 roku około godziny 00:00 do wartości 414,89 mld USD zanotowanej 17.01.2018 roku o godzinie 17:37. Z perspektywy całego rynku, spadek ten wyniósł 41,02\% (tabela 1.) (CoinMarketCap, 2018).

W tym samym czasie, kapitalizacja Bitcoina zmniejszyła się z 237,51 mld USD do 158,04 mld USD (o 33,46\%). Procentowy spadek był mniejszy niż w przypadku całego rynku kryptowalut. Cena za jednostkę Bitcoina uległa spadkowi z 14 133,20 USD do 9 402,29 USD (CoinMarketCap, 2018).

Kapitalizacja Ethereum uległa większemu spadkowi (z 128,93 mld USD do 75,78 mld USD). W tym przypadku procentowy spadek kapitalizacji był większy niż na całym rynku oraz w przypadku Bitcoina i wyniósł 41,25\%. Cena za jednostkę Ethereum uległa spadkowi z 1 329,32 USD do 780,92 USD (CoinMarketCap, 2018).

Wartość kapitalizacji Ripple spadła najbardziej ze wszystkich, analizowanych kryptowalut ( $z$ 68,83 mld USD do 34,89 mld USD, o 49,31\%). Cena jednostki uległa spadkowi $z$ 1,78 USD do 0,90 USD (CoinMarketCap, 2018).

Przyczyną kryzysu na rynku kryptowalut było m.in. oświadczenie chińskiego rządu dotyczące wszczęcia działań mających na celu zaprzestanie handlu walutami cyfrowymi w Chinach. Chińczycy mieli mieć zablokowany dostęp do platform wymiany nie tylko na rodzimym rynku, ale także tych, których siedziby były ulokowane za granicą. Celem nadrzędnym władz było ograniczenie liczby kopaczy w państwie, aby zmniejszyć zużycie energii elektrycznej (Bloomberg, 2018).

Kolejną przyczyną kryzysu, była wypowiedź S. Maijoora, pełniącego funkcję szefa Europejskiego Urzędu Nadzoru Giełd i Papie- rów Wartościowych. Oznajmił on, że rynek kryptowalut nie jest w żaden sposób chroniony i inwestorzy muszą liczyć się z możliwością utraty wszystkich, zainwestowanych środków. Kiedy bańka spekulacyjna pęknie, waluty wirtualnie nie będą już stanowić żadnej wartości (Wong, 2018).

Ponadto, padły deklaracje ze strony rządu Korei Południowej odnoszące się do zakazu handlu kryptowalutami $z$ anonimowych kont na giełdach. Korea Południowa stanowi jeden $z$ największych rynków walut cyfrowych, a tamtejszy urząd skarbowy nie był w stanie kontrolować przepływów pieniężnych na giełdach. W celu dokonywania transakcji na giełdach, konieczne będzie zweryfikowanie konta i spersonalizowanie go do tego stopnia, aby nie było problemu z określeniem wysokości należnych podatków od obywateli (Horwitz, 2018).

Kumulacja tych niekorzystnych wydarzeń spowodowała duże załamanie na rynku kryptowalut, dodatkowo napędzone poprzez panikę wśród inwestorów, których potencjalne regulacje nie miały dotyczyć. Po tym kryzysie, rynek nie odzyskał już tak olbrzymiej kapitalizacji, jaką obserwowano na początku stycznia 2018 roku.

\section{Wnioski}

Przeprowadzona analiza daje podstawy do wyodrębnienia podstawowych zdarzeń rynkowych, które miały wpływ na kształtowanie się cen kryptowalut. Były nimi:

- decyzje rządowe dotyczące regulacji rynku;

- obostrzenia podatkowe, nakładane na handel kryptowalutami w poszczególnych państwach;

- zdania ekspertów na temat rynku kryptowalut oraz prognozy co do ich przyszłej wartości;

- zmiany liczby instytucji tolerujących płatności z wykorzystaniem walut cyfrowych;

- trafianie do świadomości potencjalnych inwestorów za pośrednictwem mass mediów oraz reklam;

- nowe zastosowania kryptografii; 
- indywidualne decyzje większych inwestorów.

\section{Zakończenie}

Z przeprowadzonej analizy zdarzeń towarzyszących dynamicznym zmianom na rynku walut cyfrowych wynika, że kluczowy wpływ na koniunkturę miały decyzje rządowe oraz opinie ekspertów w sprawach rynków finansowych. Po tąpnięciu, które miało miejsce 16-17.01.2018 roku, na rynku panowały coraz gorsze nastroje. Rynek stał się coraz mniej atrakcyjny dla inwestorów, nie tylko ze względu na pogorszenie koniunktury, ale także przez dążenie wielu organów skarbowych, w tym także polskich, do ujawnienia danych osobowych klientów giełd kryptowalut. To działanie miało na celu uzyskanie informacji dotyczących należnego podatku od handlu cyfrowymi walutami. Od większości transakcji nie został odprowadzony podatek dochodowy, ponieważ wpływy budżetowe $z$ tego tytułu były bardzo małe, $w$ porównaniu $z$ obrotami giełd. Dotarcie do nowych inwestorów również było utrudnione przez blokowanie reklam nawiązujących do kryptowalut przez Google oraz Facebook. Już w styczniu 2018 roku, jako pierwszy, działania $w$ tej sprawie podjął Facebook. W połowie marca podobna polityka została przyjęta przez Google (Gibbs, 2018).

$Z$ przeprowadzonej analizy wynika również, że zarówno w przypadku korekty rynku, która miała miejsce pod koniec maja 2017 roku, hossy, którą odnotowano w drugiej połowie listopada 2017 roku oraz kryzysu z połowy stycznia 2018 roku, kryptowaluta Bitcoin była najbardziej stabilna i odporna na dynamiczne zmiany kapitalizacji rynku spośród trzech analizowanych kryptowalut.

Można przypuszczać, że wysoka wartość kapitalizacji rynku nie zostanie odzyskana, a $w$ najbliższym okresie będzie ona wynosiła 250-320 mld USD. Rynek wymiany kryptowalut jest obecnie $w$ stagnacji. Wolumen wymiany wszystkich walut cyfrowych jest mniejszy niż miało to miejsce przed 17.01.2018 roku. W przypadku Bitcoina, dzienna wartość transakcji spadła przeciętnie o $75 \%$, względem połowy grudnia 2017 roku. Popyt na kryptowaluty nie zwiększa się, ale jest to zjawisko sprzyjające stabilizacji. Nagły wzrost popytu mógłby wywołać gwałtowną sprzedaż kryptowalut. Obecnie, inwestorzy oczekują na odpowiedni moment przeprowadzenia transakcji sprzedaży, aby odnieść jak najmniejszą stratę względem kwoty za jaką dokonali zakupu. Jest wielu inwestorów, którzy chcą uwolnić fundusze ulokowane w kryptowalutach. Nagły wzrost cen mógłby skutkować kolejnym załamaniem rynku, a nawet olbrzymią utratą wartości kryptowalut, której nie zaobserwowano nigdy wcześniej (pęknięcie bańki spekulacyjnej). Takiemu rozwojowi wydarzeń nie sprzyjają kampanie prowadzone przez instytucje nadzorujące rynek finansowy w Polsce i w innych państwach. Mają one na celu zwiększenie świadomości ryzyka wynikającego $z$ inwestycji w kryptowaluty. Dzięki temu nie następuje gwałtowny wzrost popytu na waluty cyfrowe.

\section{Bibliografia}

Bloomberg. (2018). China escalates crackdown on cryptocurrency trading. Pobrane 04.04.2018 $z$ https://www.bloomberg.com.

Buterin, V. (2013). Ripple is officially open source. Pobrane 03.04.2018 $\mathrm{z}$ https://bitcoinmagazine. com.

CoinMarketCap. (2018). Pobrane 03.04.2018 z https://coinmarketcap.com.

De, N. (2017a). 'All-you-can-fly' airline begins accepting Bitcoin and Ether. Pobrane 03.04.2018 z https://www.coindesk.com.

De, N. (2017b). Deutsche Bank: blockchain opportunities are 'huge'. Pobrane 03.04.2018 z https:// www.coindesk.com.

De, N. (2017c). ECB President Draghi: cryptocurrency impact still 'limited'. Pobrane 03.04.2018 z https://www.coindesk.com.

Ethtrade. (2016). Understanding Ethereum. Pobrane 03.04.2018 z https://mightyfoxblog.files.wordpress.com.

Financial Tribune. (2017). Iran cyberspace authority welcomes Bitcoin and other crypto-currencies. Pobrane 03.04.2018 $\mathrm{z}$ https://financialtribune. com.

Gibbs, S. (2018). Google bans Bitcoin adverts in cryptocurrency crackdown. Pobrane 27.04.2018 z https://www.theguardian.com. 
Higgins, S. (2017). G-Eazy, Mariah and more to sell albums for Monero. Pobrane 03.04.2018 z https:// www.coindesk.com.

Horwitz, J. (2018). South Korea is walking back threats to ban cryptocurrency trading. Pobrane 04.04.2018 z https://qz.com.

Kądziołka, K. (2016). Inwestycje w Internecie. Bitcoin $i$ inne kryptowaluty. Warszawa: Rozpisani.pl.

Kwiecień, P. (2017). Czym jest Bitcoin i jak inwestować $w$ CFD na Bitcoin? Pobrane 03.04.2018 z https://cdn2.hubspot.net.

Nakamoto, S. (2008). Bitcoin: a peer-to-peer electronic cash system. Pobrane 03.04.2018 z https:// bitcoin.org.

Piech, K. (red.). (2017). Podstawy korzystania z walut cyfrowych. Pobrane 03.04.2018 z https://www. gov.pl.

Piotrowska, A.I. (2018). Bitcoin: płatnicze $i$ inwestycyjne zastosowania kryptowaluty. Warszawa: CeDeWu.

Sundararajan, S. (2017). Russia will 'never' consider Bitcoin legalization says minister. Pobrane 03.04.2018 z https://www.coindesk.com.
Wong, A. (2018). European regulator warns: investors could lose everything betting on new cryptocurrencies. Pobrane 04.04.2018 z https://www.cnbc. com.

Zhao, W. (2017). Hedge fund pro Miller is ' 50 percent' invested in Bitcoin. Pobrane 03.04.2018 $\mathrm{z}$ https://www.coindesk.com.

Informacje uzupełniające

Wkład autorski: autor zaakceptował ostateczną wersję artykułu.

Źródła finansowania: artykuł został w całości sfinansowany ze źródeł Uniwersytetu Mikołaja Kopernika w Toruniu.

Uwagi: wyniki badania byly zaprezentowane na VIII Ogólnopolskiej Konferencji Naukowej z cyklu Problemy gospodarki światowej (Toruń, 20.04.2018). 
Aneks

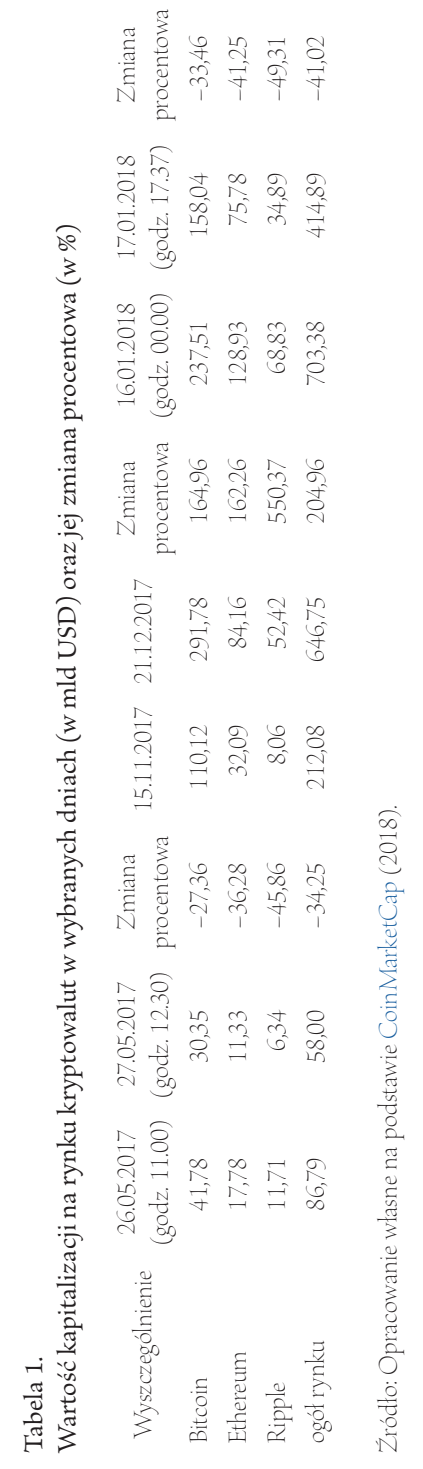


The factors determining the changes in the cryptocurrencies market

\begin{abstract}
Motivation: Currently, on the cryptocurrencies market, relevant changes are taking place; they are reflected in the fluctuations of the capitalizations of both whole cryptocurrencies market and certain cryptocurrencies. The source literature regarding those changes is missing the descriptions which would focus on the reasons behind these phenomena. Uncovering of that vague issue can bring numerous benefits, which was the main motivation for the choice of the topic.

Aim: The article aims to specify the both of factors, the ones having beneficial, and the ones having adverse influence at the value of the capitalization of the cryptocurrencies market, i.e. the market correction that took place at the end of May 2017, the bull market, which was recorded in the second half of November 2017 and the crisis from the middle January 2018.
\end{abstract}

Materials and methods: In order to define the dynamics of the market changes, the comparison of the capitalization of all the cryptocurrencies, as well as the whole market, has been made. The data regarding both above-mentioned capitalizations was obtained from the CoinMarketCap portal. In the analysis three cryptocurrencies (Bitcoin, Ethereum and Ripple), with the highest capitalization are taken into account since the fluctuations of their values have the most considerable impact on the changes in capitalization of the whole market. The situations analyzed took place in the time period between 20 April 2017 and 20 April 2018. Such a time period was chosen due to various factors involving the cryptocurrencies: the increase of the popularity, reaching wider public via mass media, and the intensification of the government's actions aiming at the implementation of new law regulations.

Results: The cryptocurrencies market, thanks to its independence from any national economy, is not influenced by the situation on the stock markets of certain countries. Among the main reasons behind the changes there are: law regulations, tax restrictions, cryptocurrencies payment acceptance, experts' opinions, the intensity of the mass media information, and the individual decisions of major investors.

Key words: cryptocurrencies; market sentiment; Bitcoin; Ethereum; Ripple JEL: F32; G12; 031 